\title{
1. \\ MODERNITET U ZAGREBU \\ POSLIJE PRVOG I DRUGOG \\ SVJETSKOGA RATA
}

\section{Ivo Goldstein}

UDK: 308(497.5 Zagreb)“19“

Pregledni rad

Sažetak: Modernitet u kontekstu ovoga članka predstavlja ukupnost onoga što čini moderan život - način modernog života i pogledi na svijet, osobito usmjerenost na težnju za napretkom i usavršavanjem kvalitete života. U povijesti Zagreba 20. stoljeće je posve specifično, radikalno drugačije od prethodnih stoljeća - između ostaloga zato što je Zagreb u tih 100 godina narastao za desetak puta, postao je političko, društveno, kulturno i industrijsko središte, odnosno velegrad. U tom smislu posve je logično da je i poslije Prvog i poslije Drugog svjetskoga rata u Zagrebu bio prisutan modernitet. Neposredno poraće u Zagrebu Prvog i Drugog svjetskoga rata, dakle prvih desetak godina (do 1928. i do 1955.), bilo je u nekim aspektima usporedivo i slično. Olakšanje nakon ratnih strahota otvaralo je nove perspektive - poslije Prvog svjetskoga rata Hrvatska i Zagreb našli su se u novom, jugoslavenskom političkom okruženju, što je otvaralo mogućnosti djelovanja na nov način, prvenstveno na ekonomskom (ali i na društvenom i kulturnom) planu. Nakon Drugog svjetskog rata, pogotovo iza 1950., nova je poslijeratna generacija iskoristila povoljne okolnosti kako bi potaknula razvoj Zagreba i na ekonomskom, i na društvenom, i na kulturnom planu. Dvadesete i pedesete, zahvaljujući dijelom i gradonačelnicima Vjekoslavu Heinzelu i Većeslavu Veci Holjevcu, uistinu su zlatne zagrebačke godine.

Ključne riječi: modernitet, Zagreb, 20. stoljeće

\1 odernitet u kontekstu ovoga članka predstavlja ukupnost onoga što čini moderan život - način modernog života i pogledi na svijet, osobito usmjerenost na težnju za napretkom i usavršavanjem kvalitete života.

U povijesti Zagreba 20. stoljeće je posve specifično, radikalno drugačije od prethodnih - između ostaloga zato što je Zagreb od 1900. do kraja stoljeća narastao za desetak puta (precizna brojka za potrebe ovog teksta nije potrebna; ovisi o tome računa li se samo uže područje grada, ili i predgrađa, ili i širi prostor koji snažno gravitira Zagrebu), postao je političko, društveno, kulturno i industrijsko središte, odnosno velegrad. U tom je smislu

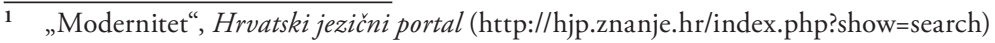


posve logično da je i poslije Prvog i Drugog svjetskoga rata u Zagrebu bio prisutan modernitet u smislu da su ga poticale i opće prilike, ali i mnogi građani.

Modernitet je vidljiv u Zagrebu i tijekom 19. i početkom 20. stoljeća, dobrim dijelom zahvaljujući željeznici koja je stigla u grad te, posljedično, industrijalizaciji, kao i priljevu novog stanovništva. Zagreb je postao relativno mala, ali vibrantna sredina na rubu velike Monarhije. Slavoljub Penkala (1871. - 1922.) i David Schwarz (1852. - 1897.) bili su genijalci, rođeni daleko od Zagreba (Penkala u Slovačkoj, Schwarz u Mađarskoj, a odrastao u Županji), ali su svoje izume razvili baš u Zagrebu. I hrvatska moderna stvarala se od kraja 19. stoljeća na zagrebačkim ulicama.

Vrlo raznorodni elementi pridonosili su u sinergiji napretku grada, odnosno modernitetu i modernizaciji. Političke elite i nakon 1918. i nakon 1945. zagovarale su političke promjene, drugim riječima, političku reformu te su se ideje prelijevale u ekonomiju, kulturu, društvo općenito, a onda iz općedruštvene klime povratno u politiku.

Nova država - Kraljevstvo SHS - u kojoj se našao Zagreb potkraj 1918. godine, obuhvatila je prostor od Alpa pa gotovo do Egejskog mora, prostor koji od 4. stoljeća nikad nije bio pod jedinstvenom upravom. Zagreb je stavljen u posve novi okvir: razgrađeno je za grad stoljećima važno srednjoeuropsko okruženje, a zauzvrat nastojala se stvoriti nova kulturna i nacionalna samosvijest južnoslavenskih naroda. Stvara se i nov, specifičan narativ: „narodno jedinstvo“ te „troimeni narod Srba, Hrvata i Slovenaca“ bili su slogani, svojevrsni „šiboleti“, kojima su bile podređene mnoge političke i javne rasprave. Želi se oponirati i „dušmanima Slavenstva“, gajiti „ljubav i svijest... pripadnost velikom slavenskom stablu“.

Stvaranjem Kraljevstva SHS Zagreb je ostao sjedište Zemaljske vlade za Hrvatsku i Slavoniju. Naizgled, davalo je to velika prava, ali je beogradska Vlada sebi dala značajne ovlasti u izvršnoj, ali i zakonodavnoj proceduri. Vidovdanskim ustavom (1921.) Zagreb je postao tek glavni grad Zagrebačke oblasti, koja nije uključivala Koprivnicu i Bjelovar, pa čak ni Karlovac i Petrinju.

Zagreb je i nakon 1918. godine, iako praktički bez upravne funkcije (Beograd je u isto vrijeme na temelju te funkcije itekako profitirao!), brzo rastao, uglavnom stoga što su se zagrebački poduzetnici uspjeli prilagoditi posve novim prilikama. Važna industrijska središta bivše Austro-Ugarske ostala su u inozemstvu pa su Zagreb, a dijelom i Hrvatska u svega nekoliko godina doživjeli dramatičnu transformaciju - postali su industrijski snabdjevač jednog posve novog političkog i ekonomskog prostora. Uz to je i agrarni potencijal Hrvatske bio mnogo veći od vlastitih potreba. Tako se Zagreb na jugoslavenskom prostoru pozicionirao kao organizacijsko, financijsko i poduzetničko središte. ${ }^{2} \mathrm{U}$ gradu je 1931. bilo gotovo 200 novčarskih i srodnih društava, od toga 75 banaka ili štedionica i 38 osiguravajućih društava. Oni su imali snažne veze u međunarodnim financijskim krugovima. ${ }^{3}$ Usporedno je jačala i industrijska proizvodnja. Stalan porast stanovnišstva i širenje urbaniziranih dijelova grada stvarali su mogućnosti za nagli razvoj svih industrijskih grana (osobito

\footnotetext{
Kratak pregled privrednog razvoja Zagreba v. u: Mira Kolar-Dimitrijević, Radni slojevi Zagreba od 1918. do 1931., Zagreb 1973., 10-12; Ivan Kampuš i Igor Karaman, Tisućljetni Zagreb, Zagreb 1975., passim.

3 I. Kampuš i I. Karaman, Tisućljetni Zagreb, 260-262.
} 
građevinarstva) - broj zaposlenih je od 1910. do 1931. porastao s 43.871 na 109.406 ili za 149,3\% (i sve to bez obzira na rat i poslijeratnu nestabilnost 1914. - 1921.). ${ }^{4}$

No, bilo je i onih koji su govorili drugačije - da je Zagreb učmala, ustajala, malograđanska sredina. Splićanin Vladimir Čerina, pobornik integralnog jugoslavenstva, piše 1914. da „ako u Zagrebu imade 80 hiljada stanovnika, 50 njih bi trebalo povesti na klaonicu, pet njih da odnese Sava, pet drugih da potopi kakav nezamišljeno silovit dažd... $s$ velikom masom od preostalih 20 hiljada, trebalo bi u kakav moralni i nacijonalni purgatorij“. Čerina tvrdi da je Zagreb „grad cinika“ i da mu treba „silom dati dušu i mozak onog grada Heroja, što se zove Beograd“, pripisuje mu „ekskluzivizam“, „šovenstvo“ i „aristokratizam“, a Beogradu „unitarizam“ (u pozitivnom smislu), „humanost“ i „demokratizam“. Valja razumjeti Čerinu: za njega, a i za druge, Zagreb je predstavljao središte hrvatskog nacionalnog pokreta, nasuprot Splitu, koji je bio ,jugoslavenskiji“. Slično piše i Milan Marjanović, koji zaključuje kako su „Zagreb i zagrebačka kafana zavod za idiotizaciju naše inteligencije".

Desničarski krugovi, s jedne strane krajnje kritični prema politici HSS-a, a s druge neprikriveni antisemiti, doživljavaju Zagreb kao omrznuti grad u kojem prevladavaju bogati aškenaski Židovi: „Zagreb! Gott der Gerechte (pravedni Bože - prijevod I. G.)! Hrvati su danas u istoj poziciji kao i Nijemci. Židovi su se tako uvukli u njihovo tijelo, da su potpuno bespomoćni protiv te kuge. Zagreb je danas predgrađe židovskog Beča. Ilica je žalosna slika hrvatske propasti. Financije su u židovskim rukama; veletrgovina i industrija također". 6

A. G. Matoš opisao je Zagreb kao „Štreberovac, glavni grad zemljice Štreberije“. No, on je također žestoko volio i branio svoj grad. ${ }^{7}$ Miroslav Krleža u autobiografskom tekstu Djetinjstvo u Agramu 1902-03. s toplinom govori o kulturi, društvu i atmosferi rodnog Zagreba (iako se nigdje ne referira na konkretna mjesta). ${ }^{8}$

Do napretka nije došlo odmah nakon rata. Ratne rane sporo su zacjeljivale. U veljači 1919. grad se zanimao za povratak kući ratnih zarobljenika, pripadnika austrougarske vojske, koji su se i dalje nalazili u zarobljeništvu u Srbiji, Italiji i Francuskoj. Bilo je mnogo invalida i siročadi. Grad je nastojao smanjiti broj čistača cipela, kao i uličnih prodavača cigareta, među kojima su se isticala djeca. ${ }^{9}$ Stizalo je i mnogo izbjeglica iz krajeva koje je okupirala Italija (ponajprije iz Istre).

$\mathrm{Na}$ lokalnim izborima u ožujku istaknuto je deset lista. Najviše su zastupničkih mjesta osvojili komunisti (odnosno SRPJ (k)) - 20 od ukupno 50, potom je slijedio HZ s 15 mjesta. Demokrati su osvojili pet, pravaši tri, pučkaši dva, Židovska lista dva te HRSS, socijaldemokrati i socijalisti jedno mjesto. Komunisti su uspjeli jer su glasači osjećali soci-

\footnotetext{
M. Kolar-Dimitrijević, Radni slojevi Zagreba, 24.

5 Vladimir ČErina, „U gradu cinika“, Vihor, 1/1914., 1; Dragovan ŠEPIĆ, Jugoslavenski pokret i Milan Marjanović 19011919. In memoriam Milanu Marjanovicu, Zagreb 1961., 539.

6 Pohod (Ljubljana), god. 1, br. 15, 17. 12. 1932., 6.

7 Antun Gustav Matoš, „Silom-budala“, u: Isti, Izabrana djela, sv. IV., Zagreb 1977., 196-201; sv. VI., 40-45, 187190.

8 Miroslav KrležA, Djetinjstvo 1902-03 i drugi zapisi, Zagreb 1972.

$9 \quad$ Ivo Perić, Zagreb od 1850. do suvremenog velegrada, Zagreb 2006., 210; Izvještaj Gradskog poglavarstva o sveopíoj upravi slobodnog i kraljevskog glavnog grada Zagreba za godine 1919. - 1925., Zagreb 1929., 15-17.
} 
jalne probleme kao bitne - naime, dvije trećine zagrebačkog radništva bili su radnici prve generacije. ${ }^{10}$

Zabranom djelovanja i represijom monarhističkog režima onemogućeno je KP-u neposrednije djelovanje u široj javnosti, ali se utjecaj lijevih ideja („progresivnih“, ali i dijelom modernizacijskih, poput općeg prava glasa, jednakosti žena, radničkog zakonodavstva itd.) i dalje osjećao, ponajprije u radničkim i dijelu intelektualnih krugova. Žene su na tim lokalnim izborima imale pravo glasa. Bio je to velik modernizacijski pomak, ali je kasnije ukinut zbog ujednačavanja glasačkog prava.

Nerazmjerno jaka u Zagrebu u odnosu na druge dijelove Hrvatske bila je Hrvatska zajednica (HZ). Nakon osnutka 1919. zagovarala je unitarizam, ali se ubrzo od njega počela udaljavati, da bi ga do sredine dvadesetih posve odbacila. ${ }^{11}$ Bila je to stranka hrvatske građanske inteligencije. Nikad nije razvila širu stranačku aktivnost te nije uspjela steći podršku širih slojeva. Protivnici su stranku podrugljivo nazivali „cilindraškom“, tvrdeći da njezin utjecaj prema jugu završava željezničkom prugom koja prolazi kroz grad (preko pruge su radnički kvartovi Trešnjevka, Trnje i drugi).

U industrijskoj proizvodnji dogodio se snažan zaokret - dok je u doba Austro-Ugarske prevladavala proizvodnja koja je neposredno iskorištavala prirodna bogatstva zemlje (osobito drvnu građu), sada se industrija vezuje za potrebe naraslih gradova. Nastaju i prvi pogoni u nekim novim granama - kemijskoj (dijelom su to bile podružnice inozemnih kompanija) i elektroindustriji. Oko 2.500 zaposlenih bilo je i u desetak poduzeća metalske grane. Domaća je proizvodnja dobila snažan poticaj 1925. uvođenjem carine na uvoz tekstila. Do sredine tridesetih tekstilna je industrija prema udjelu u proizvodnji dosegnula prvo mjesto $(27,4 \%)$, zapošljavajući tada više od 7.000 radnica i radnika. ${ }^{12}$

I te pozitivne statistike imale su svoje naličje: ekspanzija zapošljavanja dogodila se u niskoprofitabilnim djelatnostima, npr. u tekstilnoj industriji, gdje su uglavnom posao dobile nekvalificirane radnice. U Zagrebu su 34\% zaposlenih bile žene (više negoli u Sloveniji, a u Makedoniji je tada među zaposlenima bilo samo $1,5 \%$ žena). ${ }^{13}$

Dobar pokazatelj ekonomskog razvoja jest postojanje „Zagrebačkog zbora“ (danas „Zagrebački velesajam“). Nakon osmogodišnjeg prekida, prva je sajamska izložba održana 1922. na starom sajamskom prostoru između Klaoničke (danas Bauerova) i Martićeve ulice. Od 1925. održavaju se dvije godišnje izložbe, sljedeće godine već tri, narednih godina znalo ih je biti i četiri. Bilo je specijaliziranih izložaba, poput međunarodnih salona automobila. Od 1926. izložbe se održavaju u prostoru na Savskoj cesti (danas Studentski centar). ${ }^{14}$

10 M. Kolar-Dimitrijević, Radni slojevi Zagreba, 45.

11 Opširnije o HZ-u v. Hrvoje MatKović, „Hrvatska zajednica. Prilog proučavanju političkih stranaka u staroj Jugoslaviji“, Istorija XX. veka: zbornik radova, sv. 5, Beograd 1963., 5-136; Ferdo Culinović, Jugoslavija između dva rata, sv. I, Zagreb 1961., 292.

12 Zdenka Šmončić-Bobetкo, Industrija Hrvatske 1918. do 1941. godine (prir. Mira Kolar-Dimitrijević), Zagreb 2005., 300.

13 M. Kolar-Dimitrijević, „Socijalno-ekonomska politika gradske općine Zagreba s obzirom na položaj radničkog stanovništva od velike svjetske krize do početka Drugog svjetskog rata (1931-1939)“, Povijesni prilozi, 2/1983., 171; Mari-Žanin Čalić, Socijalna istorija Srbije, Beograd 2004., 244-246.

14 Državni arhiv u Zagrebu (dalje: HR-DAZG-10), fond Gradsko poglavarstvo Zagreb (dalje: GPZ), Pregled rada gradskog zastupstva (1926-1938), sjednica GZ-a 23. IX. 1935.; Od Zbora do Velesajma 1909. - 1999. 90 godina Zagrebačkog velesajma (gl. ur. Kruno Sabolić), Zagreb 1999., 56; Hrvatski narod (Zagreb), god. 1, br. 13, 5. 5. 1939., 8. 
Grade se ubrzano tramvajske pruge -1920 . bile su duge $23 \mathrm{~km}$, a onda su izgrađene pruge u Draškovićevoj i Branimirovoj te u Heinzelovoj pa je 10 godina kasnije bilo $34 \mathrm{~km}$ pruga. U istom se razdoblju povećao broj tramvajskih kola s 49 na 107. I tramvaj i autobus bili su u to doba skupi pa su se isprva radnici njima malo koristili. $S$ vremenom standard nekima raste, a i grad subvencionira javni prijevoz pa se broj putnika povećava. Tako tramvaj i autobus polako postaju masovno prijevozno sredstvo, a sve manje luksuz. ${ }^{15}$

Hotel „Esplanade“ izgrađen je 1925. godine, a tada je bio najmoderniji na Balkanu. U neposrednom susjedstvu Glavnoga kolodvora, najbolji je simbol gradogradnje tih godina. Kako se u to doba glasoviti vlak „Orient express“ zaustavljao u Zagrebu, trebalo je u gradu imati i odgovarajući hotelski smjestaj za bogatiju klijentelu. „Esplanade“ je okupljalište elite - ondje se održavaju prve modne revije (1926.), prvi izbor za miss Zagreba (1927.), gostuje Josephine Baker... ${ }^{16}$

Zagreb je u dvadesetima doživio i snažan razvoj sveučilišnog života - desetljećima su postojali samo Filozofski, Pravni i Teološki fakultet, a 1918. osniva se medicina, na kojoj se u sljedećih nekoliko godina otvara desetak zavoda i klinika. U dvadesetima osnivaju se Poljoprivredno-šumarski, Veterinarski fakultet (do 1926. Visoka veterinarska škola) te Visoka tehnička škola (od 1926. Tehnički fakultet, koji osniva pet odjela - Arhitektonski, Građevinski, Geodetski, Elektrotehnički i Rudarski - začetke budućih fakulteta). Tada je djelovala i Ekonomsko-komercijalna visoka škola (kasnije Ekonomski fakultet). Sve je više studentica. Zagrebačka omladina koja želi studirati sve manje ima potrebu odlaziti na studij u inozemstvo. ${ }^{17}$

Andrija Štampar je od 1919. kao načelnik higijenske službe Ministarstva narodnog zdravlja stvarao jugoslavensku javnozdravstvenu službu, utemeljenu na prosvjećivanju naroda i širenju zdravstvene zaštite na radničke slojeve koji su bili slabo plaćeni, živjeli u higijenski neprikladnim stanovima i radili u nesigurnim uvjetima. Njihovo zdravlje sada „postaje objekt nacionalne ekonomije, a ne ostaje samo subjekt“. Kao i svaka novìna, Štampar i njegove ideje imale su protivnike: optuživalo ga se da je "potpao pod socijalistički utjecaj“, da mu se „reforma temelji na komunističkim principima“ te da je „abnormalan i psihopat“. U pozadini svih tih argumenata za spašavanje narodnog zdravlja od boljševičke opasnosti nalazila se obrana „staleških i ekonomskih interesa“. Usprkos svim otporima, Štampar je kao krunu svojih napora osnovao 1927. u Zagrebu Školu narodnog zdravlja, kasnije nazvanu po njemu. ${ }^{18}$

Iako su se određeni sadržaji selili prema periferiji, trgovački se život i dalje koncentrirao u središtu grada. Četverokatna robna kuća „Kastner i Öhler“ na početku Ilice, otvorena 1928., i tržnica na Dolcu (otvorena 1930.) bile su žile kucavice gradske trgovine.

Još pred Prvi svjetski rat osnova „tjelesnog uzgoja“ bila je gimnastika, ali su se gimnazijalci (dakle, učenici od 11 do 19 godina) bavili i „različnim športskim igrama (lawn-tennis,

15 Zagrebački električni tramvaj: 105 godina (ur. Vlado Šobota), Zagreb 1996., 17, 47; Povijest grada Zagreba, knj. 2: 20. i 21. stoljeće, Zagreb 2013., 33, 66.

16 Tomislav Timet, Stambena izgradnja Zagreba do 1954. godine, Zagreb 1961., 154.

17 HR-DAZG-10, fond GPZ, Pregled rada gradskog zastupstva (1926-1938), sjednica GZ-a 24. III. 1938.

18 Tomislav Kostović, Škola narodnog zdravlja u borbi protiv alkoholizma u međuratnoj Hrvatskoj, diplomski rad, Zagreb 2018. 
hockey, nogomet, bocca itd.)“, kao i „floretovanjem i mačovanjem“. ${ }^{19}$ Bili su to sportovi kojima se bavila uglavnom društvena elita. Nogomet je bio iznimka jer je vrlo brzo postao jako popularan: državne su vlasti čak 1920. slale okružnicu srednjim školama sa zahtjevom da se „temeljito pretrese“ činjenica kako se „od nekog vremena razvio vanredno šport kod naše srednjoškolske omladine... osobito se opazilo veliko sudjelovanje kod nogometa; događa se da ovo sudjelovanje katkada toliko okuplja našu mladež, da zanemaruje i školsku obuku, te i sami roditelji dolaze pojedinim ravnateljstvima s molbom da se ta igra zabrani“ ${ }^{20}$ Nogomet nije, naravno, bio zabranjen, već će ga u narednim godinama sve više igrati i pripadnici radničkog sloja pa se na periferiji gradi niz nogometnih igrališta. ${ }^{21}$

Grade se i kina: do 1928. izgrađeno ih je šest. Vlasnike kina dijelom se oslobađalo poreza, ali je grad zauzvrat tražio besplatan ulaz „sve djece gradskih dječjih konaka i siromašne djece iz gradskih pučkih škola do $30 \%$ ukupne školske djece, koja će pod nadzorom učitelja i učiteljica polaziti predstave“. 22

Život se dobrim dijelom odvijao u kavanama: u Zagrebu ih je 1930. bilo $19 .{ }^{23}$

Vrlo značajan dokaz o poduzetničkoj, kulturnoj i tehnološkoj zrelosti Zagreba bilo je i osnivanje Radio Zagreba. Radio klub osnovan je 1924., sljedeće godine dobiva koncesiju, a potom i odobrenje Vlade Kraljevine SHS da može osnovati Dioničko društvo Radio Zagreb.

Afirmacija žena i problematiziranje njihova položaja u društvu odvijali su se vrlo sporo. Marija Jurić Zagorka pokrenula je u Zagrebu 1925. i uređivala Ženski list: za modu, zabavu $i$ kućanstvo, prvi hrvatski časopis namijenjen isključivo ženama. Poput Europe i SAD-a u prethodnim desetljećima, i u Zagrebu su se počele otvarati trgovine odjećom; velik izbor i relativno niske cijene počeli su dokidati proizvodnju odjeće kod krojača. Nakon rata u modu su ušle kraće suknje ravnih linija (do koljena) i Zagreb je to prihvatio.

Svemu tome bilo je i otpora: Ksaver Šandor Gjalski, glasoviti, ali ostarjeli 75-godišnji književnik, vidio je potkraj dvadesetih ženu u kavani koja je prebacila nogu preko noge pa su joj se vidjela bedra. Tvrdi da su „ovu modu kratkih sukanja i kratke frizure stvorili pariski Židovi-krojači i Židovi-trafikanti“ te da su „dražesnu mulatkinju Josefinu Baker zanosno i udivljeno dočekali domaći i doseljeni Židovi“. ${ }^{24}$

U dvadesetima je i karijera Miroslava Krleže u usponu. Iako mu je s repertoara HNK-a u Zagrebu zbog njegova revolucionarno-ljevičarskog stava i antimilitarizma skinuta drama Galicija, njegovi su časopisi Plamen i Književna republika (1923. - 1927.) u temeljima hrvatskog modernizma. Važan je bio i Plamen Augusta Cesarca, kao i Zenit, okrenut avangardnoj umjetnosti, koji je pod uredništvom Ljubomira Micića izlazio u Zagrebu (1921. - 1923.), a potom u Beogradu.

No, sav taj modernitet Hrvati iz poplavljenog Trnja i oni iz hotela „Esplanade“ ne doživljavaju jednako, kao da i ne pripadaju istoj povijesti/naciji: jedni se obmanjuju da su u

19 Izvještaj Kraljevske gornjogradske velike gimnazije za 1913-1914, Zagreb 1914., 79.

20 HR-DAZG-102, fond I. klasična gimnazija, sign. 24964, kut. 55, god. 1920., 660.

21 M. Kolar-Dimitrijević, Radni slojevi Zagreba, 202.

22 Skupštinski zapisnici slob. i kraljev. glavnog grada Zagreba, 1920., Skupština od 18. X. 1920.

23 I. PERIĆ, Zagreb od 1850. do suvremenog velegrada, 229.

24 Ivo Goldstein, Židovi u Zagrebu 1918-1941., Zagreb 2004., 140. 
„Evropi“, a drugi žive „zaostalo žalosno balkansko stanje“, kako je to 1926. zapisao Krleža. ${ }^{25}$

Nakon oslobođenja u svibnju 1945., modernitet i modernizacija bili su snažno naglašeni. Isprva im je poticaj davala stečena sloboda. O njoj je najljepše govorio predsjednik Sabora Vladimir Nazor 16. svibnja 1945. na Jelačićevu trgu na velikom narodnom zboru: „Nosimo ti, grade Zagrebe, novi duh, novi narodni život... a to je sloboda i jednakost između svih ljudi. Nosimo ti mladost uvijek spremnu na otpore i borbu protiv zla. Nosimo ti vjeru u svoju sposobnost i u svoje ideale. Nosimo ti ljubav prema svakom Hrvatu, prema čovjeku uopće ma kojeg jezika, ma koje vjere, ma kojeg zanimanja i socijalnog sloja on bio. Naš moral, naša etika, nisu moral i etika okupatora i domaćih špekulanata i izdajica. Zagrepčani Hrvati i svi narodi federalne države Hrvatske, mi borci za narodno oslobođenje, mi tako zvani partizani nosimo vam iz naših šuma ono, što se na planinama najviše osjeća, pravu bit slobode uopće“. ${ }^{26}$ Međutim, ta će sloboda biti zastrta petogodišnjim razdobljem staljinizma, u kojem se grad prilično brzo oporavio od rata, ali nije doživio onakvu slobodu za kojom je u ratu čeznuo.

Krenula je obnova. U prvim poslijeratnim godinama javni je život bio u znaku početne radosti osloboditelja i oslobođenih, a zatim i entuzijazma obnove i izgradnje („Dok traje obnova, nema odmora!").

Važna je bila i parola „nema povratka na staro“, pod kojom se vodila borba protiv tradicionalizma, a modernitet je bio jedno od sredstava u toj borbi. „Modernizacija“ je bila ključan ideologem na kojem se gradila ideologija jugoslavenskog socijalizma. Poticao ju je i sâm Josip Broz Tito, koji se, među ostalim, zalagao za nestanak „zastarjelih shvatanja“ o tradicionalnom položaju žene. Tito i suradnici svjesno su odabrali boljševički model društvenih odnosa, „koji je u suštini bio obrazac modernizacije zaostalih agrarnih ekonomija planskom industrijalizacijom“. Smatralo se da se takvom političkom praksom najbrže i najlakše mogu realizirati zadani ciljevi socijalizma: ponajprije, da jednu siromašnu agrarnu zemlju transformira u industrijsku, što je, ako se to shvaća kao modernizacija, bilo nužno i neizbježno. ${ }^{27}$

$\mathrm{Na}$ temelju petogodišnjeg plana razvitka FNRJ (1947. - 1952.) doneseni su planovi razvitka po republikama te za njihove glavne gradove. U Zagrebu se vehementno najavljivalo da je „potrebno izvršiti rekonstrukciju privrednog, kulturnog i društvenog života Zagreba u duhu nove društvene stvarnosti, koja će omogućiti njegov pravilan i brz razvitak“, sve „u cilju poboljšanja životnih uslova građana“. Ističe se novi vodovod, povećanje kapaciteta gradske plinare i elektrane, kao i „nove škole, domovi kulture, dječji domovi, đački domovi, domovi učenika u privredi i druge kulturne, socijalne i zdravstvene ustanove“. Od velikog je značenja i „gradnja tunela ispod Sljemena, rješenje željezničkog čvorišta i plovnog kanala, te velikog broja stambenih i uredskih zgrada“. Naposljetku, naglašeno je da treba „voditi računa prvenstveno o periferijskim rajonima i tako postepeno uklanjati razliku iz-

25 M. KrležA, „O malograđanskoj ljubavi spram hrvatstva“, u: Isti, Deset krvavih godina i drugi politički eseji, Zagreb 1957., 124-127.

26 Vjesnik (Zagreb), god. 5, br. 23, 17. 5. 1945., 1.

27 Opširno u: I. Goldstein i Slavko Goldstein, Tito, Zagreb 2015., 313 i literatura. 
među uređenog centra i zapuštene periferije što je rezultat politike kapitalističke vladavine.“ Znatne su investicije predviđene i za lokalnu industriju. ${ }^{28}$

Nešto je od najavljivanog i ostvareno: omladinci su 1948. izgradili prugu od Dubrave do Markuševačke Trnave, dugu $6 \mathrm{~km}$, kojom su stanovnici tih predgrađa odlazili na posao, dovozili poljoprivredne proizvode na gradske tržnice, kao i šljunak u grad. Pruga je imala i propagandističku važnost jer je završavala pred budućim Pionirskim gradom. „Samoborček“ je sličnu funkciju imao u zapadnim predgrađima. ${ }^{29}$ Stari „Samoborček“ je 1959. zamijenjen novim, „Srebrnom strijelom“ (u ironičnom žargonu „vlak od pleha"), jednim od prvih vlakova uopće izgrađenim od aluminija. Tramvajska je pruga 1950. stigla do Gračana, čime su dotadašnja podsljemenska sela dobila kvalitetnu vezu s centrom, a Zagrepčani prijevozno sredstvo za izlete na Medvednicu.

Raskid sa Staljinom i postupna liberalizacija počeli su se u Zagrebu osjećati 1951./1952. godine, kada se naglo promijenilo i samo lice grada. Na Trgu Republike prvi su put osvanule goleme neonske reklame. Na kioscima su se odjednom mogle kupiti inozemne novine - Le Figaro, La Stampa, Frankfurter Rundschau. Naslovne stranice domaćih dnevnika više nisu bile dosadne sive plahte poput Pravde ili Izvjestije, već privlačno živahne, nalik na Corriere della Sera. Pred kinima, u kojima su igrali novi filmovi sa Zapada, redovito se tražila „karta više“, na čemu su poduzetni preprodavači sasvim lijepo zarađivali. Jedan za drugim otvarali su se novi plesnjaci u kojima je treštao jazz. ${ }^{30}$

Došlo je i do značajnih pomaka u umjetnosti. Napuštaju se do tada dominantni socrealistički obrasci, a javljaju se neki posve avangardno-modernistički postupci. Stjegonoša tih pomaka bila je generacija tridesetogodišnjaka i mlađih. Primjerice, grupa arhitekata i umjetnika koja se nazivala „EXAT 51“ izdaje 1951. u Zagrebu manifest, koji svoja bitna ishodišta nalazi u nekim zasadama Bauhausa i konstruktivističke umjetnosti. Prvu je internu izložbu grupa organizirala sljedeće godine u atelijeru jednog od članova, Ivana Picelja, a 1953. i prvu javnu izložbu. Edo Murtić 1951. odlazi u SAD i pod dojmom tamošnjih velegradskih vizura izrađuje ciklus slika naglašenih gestualno-ekspresionističkih karakteristika koji ubrzo izlaže u Zagrebu i Beogradu.

U Zagrebu 1952. počinje izlaziti književni časopis Krugovi, u kojem će se promovirati znatno slobodniji pristup književnosti: „krugovaši“", koji su se sastajali u prostorijama Društva književnika Hrvatske, socrealizmu su suprotstavili „prozu u trapericama“ i suvremenu tematiku. Lirika im je bila poticana egzistencijalizmom i nadrealizmom, a kritika utemeljena na recentnim svjetskim teorijama - „nova umjetnost tek treba da se rodi“, kaže u programatskom članku jedan od krugovaša Vlatko Pavletić te dodaje: „Dijalektički materijalizam? Socijalistički? Realizam apsurda? Ili jedan od izama?... Programi, pravci i firme najmanje su važni.“"31 Zagreb je početkom pedesetih proživljavao neke od svojih najvibrantnijih trenutaka u 20. stoljeću.

\footnotetext{
28 HR-DAZG-37, fond Narodni odbor grada Zagreba, Zapisnici sjednica Gradskog narodnog odbora, podfond 6 (1948. godina), 335, 355-356.

29 HR-DAZG-965, fond Gradska željeznica Zagreb; Novi list (Rijeka), god. 63, br. 20.031, Poslovni prilog za gospodarstvo i financije, br. 631, 15. 7. 2009., 3; Klub željezničkih modelara „Zagreb“ (http://www.kzmz.hr/zanimljivosti. asp?page_id=zanimljivosti); Službeni glasnik Narodnog odbora grada Zagreba, 36/1950.

30 S. Goldstein, 1941.: godina koja se vraća, Zagreb 2007., 463.

31 Vlatko Pavletić, „Neka bude živost“, Krugovi, 1/1952., 3.
} 
Propadanje koncepta po kojem bi Partija u ždanovljevskom duhu nametala „sloganskoplakatno" shvaćanje uloge kulture propao je i prije nego što su i vlast i oni koji su priželjkivali više slobode planirali i očekivali. Želja i potreba da se u novim unutarnjim i vanjskopolitičkim okolnostima pokaže, posebno Zapadu, „demokratičnost“ jugoslavenskoga režima u odnosu na sovjetski dogmatizam pripomogla je tomu da se popuštanje ideološke stege u kulturi, dobrim dijelom baš u Zagrebu, dogodi prije značajnije političke demokratizacije. ${ }^{32}$

Od 1952. do 1963. godine zagrebački je gradonačelnik (ili, kako je glasila službena titula, „predsjednik Gradskog narodnog odbora Zagreba“) bio Većeslav Veco Holjevac (1917. - 1970.), legendarni partizanski komandant. U tih je 11 godina Zagreb napravio odlučne korake u transformaciji jednog tipičnog srednjoeuropskoga grada prema velegradu.

Holjevcu su u prilog išla i pozitivna ekonomska očekivanja. Bilo je to doba rasta i optimizma, otvaranja perspektiva. ${ }^{33} \mathrm{U} 11$ godina svoga mandata Holjevac se, za razliku od većine komunističkih kadrova, nije zadovoljio time da bude puka transmisija volje viših foruma. Djelovao je samostalno i energično, a bio je, osim toga, za razliku od drugih rukovodilaca u to doba, i omiljen među građanima. Sve je to pretočeno u realizaciju niza izvrsnih projekata.

Rast broja stanovnika jedna je od temeljnih činjenica povijesti Zagreba u poslijeratnom razdoblju. Godine 1948. grad je imao 314.669 stanovnika, a prema popisu iz 1953. već 350.829 , što čini povećanje od 11,5\%. Do sljedećeg popisa stanovništva 1961., dakle u samo osam godina, grad je narastao za daljnjih 22,8\% (imao je tada 430.802 stanovnika), da bi do novog popisa 1971. porastao za novih 135.000 stanovnika ili daljnjih 31,4\%, čime je dosegnuo brojku od 566.224 stanovnika.

U rubnim dijelovima grada broj se stanovnika ubrzano povećavao - u samo osam godina, od 1953. do 1961., stanovništvo u Dubravi naraslo je za čak 186\%. U sljedećem statističkom razdoblju, od 1961. do 1971., povećalo se za 144\%, a stanovništvo Vrapča i Španskog za čak $247 \%$, odnosno $578 \% .{ }^{34} \mathrm{~S}$ druge strane, broj se stanovnika u samom centru smanjio (od 1953. do 1961. u tadašnjoj općini Donji grad za 6,3\%), što je dijelom rezultat povećanja stambenog standarda - pri čemu se mnogi iseljavaju iz malih i neudobnih stanova u nove na periferiji - kao i pretvaranja stambenog prostora u poslovni.

Tako je polako nestajala socijalna segregacija, koju je prije rata simbolički i fizički potencirala željeznička pruga jer se nove, kvalitetne poslovne i stambene zgrade grade ponajprije južno od pruge. Istovremeno, uslijed starosti pojedinih zgrada ili čitavih ulica u Donjem, a pogotovo u Gornjem gradu, stambene se prilike u njima zapravo pogoršavaju.

Od pedesetih, a na temelju starog plana još iz 1936. godine, novi se centar grada počinje izgrađivati uz središnju modernu prometnicu - tada Moskovsku aveniju, kasnije nazvanu

32 Milan Ristović, „Jedno viđenje prelomne godine jugoslovenske posleratne kulturne politike (1952)“, 338-341, 347, 350. (https://dokumen.tips/documents/7248-milan-ristovic-jugoslovenske-posleratne-kulturne-politike.html)

33 Dušan Bilandžıć, Hrvatska moderna povijest, Zagreb 1999., 45, 215-239; I. Goldstein, Hrvatska 1918-2008., Zagreb 2008., 490 i dalje.

34 Mirko Korenčić, Naselja i stanovništvo SR Hrvatske 1857-1971., Zagreb 1979., 766-773; Ivan CRKVENČIĆ, „Socijalno-geografska struktura rubnih dijelova Zagreba“, u: Zbornik VIII. kongresa geografa SFRJ, Skopje 1968., 254; Zagrebačka panorama, 1/1961., br. 6, 142-145. 
Ulicom proleterskih brigada (danas Vukovarska). Samo koju godinu kasnije podižu se prve zgrade u Savskom gaju i počinje izgradnja „Velesajma“.35

Izgradnja Mosta slobode 1959. otvara posve nove perspektive - zapravo, stvara se moderni Novi Zagreb, koji se, manje ili više otvoreno, predstavljao kao pandan izgradnji Novog Beograda. Zgrada i putnička stajanka novog zagrebačkog aerodroma završene su iste godine (1959.), a tri godine kasnije službeno je otvoren aerodrom „Pleso“. U prvoj je godini rada njime prošlo 78.000 putnika, 633 tona tereta i 5.206 aviona. Do 1974. promet je rastao prema prosječnoj godišnjoj stopi od $35 \%$ putnika, $25 \%$ aviona i $30 \%$ tereta. $^{36}$

U pedesetima stvaraju se velike tvornice, ojačane nakon nacionalizacije potkraj četrdesetih godina i fuzioniranjem više manjih poduzeća. „Končar“ je 1939. imao 114 radnika, 1955. ima ih već 3.560 , „Prvomajska“ u isto vrijeme raste sa 140 na 1.850, „Bratstvo“ s 11 na 240 , „Jedinstvo“ s 12 na 650, a Tvornica parnih kotlova s 25 na 600 radnika. ${ }^{37}$ Slični su trendovi i u tvornici pića „Badel“, potom u kemijskom kombinatu „Chromos“, pa u Tvornici čokolade „Josip Kraš“, tvornici namještaja „Šavrić“ i elektroindustriji „Nikola Tesla“.38

Dolazi do velikog povećanja broja fakulteta: od 1955., kada je bilo devet fakulteta, u sljedećih trinaest godina, do 1968., taj je broj porastao na 26 fakulteta i pet visokih škola, 13 sveučilišnih instituta i tri sveučilišne ustanove. Primjerice, jedinstveni Tehnički fakultet je 1956. preustrojen i podijeljen na četiri fakulteta: Arhitektonsko-građevinsko-geodetski, Strojarsko-brodograđevni, Elektrotehnički i Kemijsko-prehrambeno-rudarski fakultet. U toj grupaciji, nakon višekratnih organizacijskih promjena, 2019. djeluje čak 12 fakulteta.

Filozofski je fakultet prve šk. g. 1874./1875. imao šest profesora na šest katedri i 26 studenata. Otada i broj nastavnika i broj studenata ubrzano raste. Iz današnje zgrade Sveučilišta na Trgu maršala Tita, na kojoj se nalazio desetljećima, Fakultet se 1961. seli u novu zgradu u Ulici Đure Salaja (danas Lučićeva).

I u samom se centru mnogo gradi: nakon prvog zagrebačkog nebodera, izgrađenog 1933 . na uglu Masarykove i Gundulićeve, 1958. dovršen je deseterokatni neboder („Drvoder“) na uglu Martićeve i Smičiklasove. Mnogo važniji korak u uzdizanju Zagreba prema visinama dogodio se sljedeće godine, kada je otvoren „Neboder“ („Zagrebački neboder“) na Trgu Republike (danas Jelačićev trg) koji postaje jedan od simbola grada. Ostakljeno aluminijsko pročelje bilo je i vjesnik novoga doba, osobito moderne arhitekture.

Izgradnja prekosavskih naselja počinje 1957. godine - najprije Savskoga gaja i Naselja februarskih žrtava u Remetincu. Dvije godine kasnije počinje izgradnja naselja Trnsko, u kojem se nastojalo cjelovito riješiti stanovanje, javne i trgovačko-uslužne sadržaje. Od 1952. gradi se - a od 1955. vrlo intenzivno - „Zagrebački velesajam“, zapravo novi sajamski grad na površini od $165.000 \mathrm{~m}^{2} \mathrm{~s}$ nizom izložbenih paviljona, poslovnih prostora, ugostiteljskih objekata, aleja i parkova. „Velesajam“ je bio jedan od motora razvoja čitavoga grada.

Izgradnjom u udaljenijim dijelovima grada decentralizira se i trgovina, dotad koncentrirana u užem centru: trgovci dugo nisu imali računicu otvarati trgovine na periferiji jer su

\footnotetext{
35 Valentina Gulin ZRnić, Kvartovska spika. Značenje grada i urbani lokalizmi u Novom Zagrebu, Zagreb $2009 ., 43$.

36 Zagrebački leksikon 2 / M-Ž, Zagreb 2006., 581-582; Vjesnik (Zagreb), god. 43, br. 12646, 11. 11. 1982., 6; Vjesnik (Zagreb), god. 43, br. 12646, Delegatski Vjesnik, god. 8, br. 213, 11. 11. 1982., 7-8.

37 Vjesnik (Zagreb), god. 16, br. 3182, 29. 5. 1955., 2.

38 Isto; Zagrebački leksikon 2, 448.
} 
one u centru, dijelom zahvaljujući i navikama kupaca da za svaku ozbiljniju kupnju idu u centar, ostvarivale puno veći promet. ${ }^{39} \mathrm{Ključan} \mathrm{pomak} \mathrm{u} \mathrm{decentralizaciji} \mathrm{trgovine} \mathrm{napravila}$ je „NAMA“, koja otvara robne kuće od Dubrave do Kustošije i sve do Trnskog.

Izgled grada mijenjao se i automobilizacijom - dok je 1945. na području grada bilo registrirano manje od tisuću putničkih automobila, polovinom pedesetih već ih je bilo 4.375, a do 1967. čak 27.716.

Poticaji razvoju građanskih obrazaca javnoga komuniciranja na jugoslavenskom prostoru stizali su opet upravo iz Zagreba: Vjesnik u srijedu pokrenut je 1952. kao prvi jugoslavenski revijalno-politički tjednik širokog spektra. U nekim je razdobljima dosezao nakladu od 300.000 prodanih primjeraka te snažno utjecao na razvoj medijskog prostora i društva općenito. Ubrzo je, sljedeće godine, pokrenuta i ženska revija Svijet, da bi 1954. izašao prvi broj tinejdžerskog tjednika Plavi vjesnik. Nešto kasnije (1959.) počinju izlaziti tjedne revije Globus i Arena. Potonja počinje kao „polumjesečna revija za film i televiziju“, da bi ubrzo postala ilustrirani zabavni tjednik, odnosno obiteljski list sa sadržajima iz običnoga, svakodnevnog života i takva će ostati u narednim desetljećima.

Dinamična događanja na medijskoj sceni dodatno su intenzivirana 1959. godine, kada su se Narodni list (1945. - 1959.) i Večernji vjesnik (1957. - 1959.) spojili u Večernji list, koji je osamdesetih godina postao najtiražniji dnevnik u povijesti zagrebačkog i hrvatskog novinstva (više od 300.000 prodanih primjeraka dnevno).

Zagrebačko je izdavaštvo u poslijeratnom razdoblju imalo izuzetnih uspjeha: u mnogočemu je prednjačilo i u jugoslavenskim okvirima. Miroslav Krleža je 1950. osnovao Leksikografski zavod (od 1984. Jugoslavenski leksikografski zavod Miroslav Krleža). Temeljni projekt Zavoda bila je Enciklopedija Jugoslavije: prvi od osam svezaka izašao je iz tiska 1955. godine, a ukupno je do 1988. izašla u tri izdanja. Slijedio je niz enciklopedijskih izdanja, projekti nacionalnog značenja te leksikoni, atlasi i drugi priručnici.

Nakladni zavod Hrvatske je već nakon osnivanja 1945. pokrenuo niz važnih serija, a potom je 1949. preustrojen te su iz njega nastala važna izdavačka poduzeća - Zora i Školska knjiga, kao i dugo vremena najjača hrvatska tiskara, ona Grafičkog zavoda Hrvatske.

U ovom je razdoblju i kazališni život dobio snažan poticaj - godine 1950. organizirana je glumačka kuća „Komedija“, koja od osnivanja izvodi bogat repertoar vedrih kazališnih djela: operete i komične opere izvode se od osnutka, a od 1960. mjuzikli. ${ }^{40}$

Nakon peticije tridesetak uglavnom mlađih umjetnika, predvođenih Branko Gavellom, da se osnuje drugo zagrebačko kazalište, koje bi svojim repertoarom i stilom bilo protuteža HNK-u kao središnjoj i tradicionalistički usmjerenoj nacionalnoj kući, osnovano je 1954. Zagrebačko dramsko kazalište u Frankopanskoj ulici kao samostalna ustanova (dotad je funkcionirala kao manja pozornica HNK-a, a danas nosi ime svoga osnivača Branka Gavelle). U njemu se izvode djela svjetskih klasika (Beckett, Ionesco, Anouilh i drugi) te suvremenih domaćih pisaca. Tijekom šezdesetih osvježenje kazališnog života dogodilo se 1964. osnivanjem Satiričkog kazališta „Jazavac“ (od 1994. „Kerempuh“), koje je svojim zabavnim repertoarom postalo jednim od popularnijih zagrebačkih kazališta. 
Godine 1950. u Zagrebu je bilo 18 kina, da bi ih 1965. bilo 35. Usporedno raste i broj gledalaca: od 5,753.000 godine 1950. do čak 10,267.000 godine 1960. Otad broj posjetitelja pada, uglavnom zato što se nalaze druge vrste zabave, prvenstveno TV.

Iz skučenih prostora u Vlaškoj ulici postupno se u novoizgrađeni kompleks „filmskoga grada“ u Dubravi od 1954. seli „Jadran film“. Nova lokacija omogućila je „Jadran filmu“ da bude ne samo najveće hrvatsko filmsko poduzeće, nego da se razvije i ostane (sve do početka devedesetih) najveći i najpoznatiji filmski studio u Srednjoj Europi (pogotovo nakon što se ranih šezdesetih ujedinio $s$ „Dubrava filmom“, koji je dotada bio samo tehnička baza). U njemu je u tom razdoblju snimljeno 145 međunarodnih koprodukcija i 124 domaća filma te su ugošćene neke od tada najvećih filmskih, redateljskih i glumačkih zvijezda (Omar Sharif, Richard Burton, Yul Brynner, Anita Ekberg).

U takvom okruženju, od početka pedesetih, svoje prve knjige u Zagrebu objavljuje Vladan Desnica.

\section{$\cos$ \\ The MOdernity in Zagreb AFter THE First and SEcond World War}

Summary: For the purposes of this paper, modernity shall be regarded as the totality of what comprises modern life and outlook, particularly in terms of striving towards progress and the improvement of the quality of life. The $20^{\text {th }}$ century is a peculiar chapter in the history of Zagreb, radically different from the centuries that preceded it - among other things, between the years 1900 and 2000 Zagreb grew in size ten times (a more precise calculation would depend on whether only the city itself is taken into consideration, or its suburbs and the entire metropolitan area that gravitates to it as well). During that time, the city turned into a political, social, cultural and industrial center; essentially transforming into a metropolis. In that sense, it is entirely logical that the aftermaths of World War I and World War II were marked by a degree of modernity, fueled in equal parts by the citizens themselves and the general circumstances. Modernity first took hold of Zagreb in the $19^{\text {th }}$ and the early $20^{\text {th }}$ centuries, largely owing to the arrival of the railroad, which generated industrialization and population growth. Although comparatively small, Zagreb became a vibrant community on the outskirts of the great Monarchy. A synergy of a wide variety of elements contributed to the city's prosperity, modernity and modernization. After 1918 and 1945 alike, political elites advocated political change, i. e. political reform. Their ideas impacted the economy, culture and society in general, before being reflected back into politics. The immediate aftermath of both wars, or more precisely, the first decades of peacetime (ending with 1928 and 1945 respectively) shared a number of similarities, as the relief that was brought about by the cessation of bloodshed created new possibilities. After the First World War, Zagreb found itself in a new political context, the Yugoslav one, which opened up new opportunities for development, primarily in terms of the economy, but also culture and society. Likewise, after the end of the Second World War, but particularly after 1950, the emerging postwar generation used the new favorable circumstances to jumpstart the social, economical and cultural development of the city. Therefore it can be said that the 1920s and the 1950s, owing in part to the efforts of the then-mayors Vjekoslav Heinzel and Većeslav-Veco Holjevac, truly represent, each in their own way, a golden age in the history of Zagreb.

Key words: modernity, Zagreb, the $20^{\text {th }}$ century 


\section{$\cos$}

\section{Izvori}

Državni arhiv u Zagrebu (HR-DAZG)

HR-DAZG-10, fond Gradsko poglavarstvo Zagreb (GPZ), Pregled rada gradskog zastupstva (1926-1938).

HR-DAZG-37, fond Narodni odbor grada Zagreba, Zapisnici sjednica Gradskog narodnog odbora, podfond 6 (1948. godina).

HR-DAZG-102, fond I. klasična gimnazija, sign. 24964, kut. 55.

HR-DAZG-965, fond Gradska željeznica Zagreb.

Izvještaj Gradskog poglavarstva o sveopćoj upravi slobodnog i kraljevskog glavnog grada Zagreba za godine 1919. - 1925., Zagreb 1929.

Izvještaj Kraljevske gornjogradske velike gimnazije za 1913-1914, Zagreb 1914.

Skupštinski zapisnici slob. i kraljev. glavnog grada Zagreba, 1920.

Hrvatski narod (Zagreb), 1939.

Novi list (Rijeka), 2009.

Pohod (Ljubljana), 1932.

Službeni glasnik Narodnog odbora grada Zagreba, 36/1950.

Vjesnik (Zagreb), 1945., 1955., 1971. - 1972., 1982.

\section{Literatura}

Dušan BILANDŽIć, Hrvatska moderna povijest, Zagreb 1999.

Ivan CRKvenČIĆ, „Socijalno-geografska struktura rubnih dijelova Zagreba“, u: Zbornik VIII. kongresa geografa SFRJ, Skopje 1968., 253-266.

Mari-Žanin Čalić, Socijalna istorija Srbije, Beograd 2004.

Vladimir ČErIna, „U gradu cinika“, Vihor, 1/1914., 1.

Ferdo Čulinović, Jugoslavija između dva rata, sv. I, Zagreb 1961.

Ivo Goldstein, Hrvatska 1918-2008., Zagreb 2008.

Ivo Goldstein, Židovi u Zagrebu 1918-1941., Zagreb 2004.

Ivo Goldstein i Slavko Goldstein, Tito, Zagreb 2015.

Slavko Goldstein, 1941.: godina koja se vraća, Zagreb 2007.

Valentina Gulin Zrnić, Kvartovska spika. Značenje grada i urbani lokalizmi u Novom Zagrebu, Zagreb 2009.

Ivan Kampuš i Igor Karaman, Tisućljetni Zagreb, Zagreb 1975.

Mira Kolar-Dimitrijević, Radni slojevi Zagreba od 1918. do 1931., Zagreb 1973.

Mira Kolar-Dimitrijević, „Socijalno-ekonomska politika gradske općine Zagreba s obzirom na položaj radničkog stanovništva od velike svjetske krize do početka Drugog svjetskog rata (19311939)“, Povijesni prilozi, 2/1983., 171-244. 
Mirko Korenčić, Naselja i stanovništvo SR Hrvatske 1857-1971., Zagreb 1979.

Tomislav Kostović, Škola narodnog zdravlja u borbi protiv alkoholizma u mecuratnoj Hrvatskoj, diplomski rad, Zagreb 2018.

Miroslav Krleža, Djetinjstvo 1902-03 i drugi zapisi, Zagreb 1972.

Miroslav KrLEŽA, „O malograđanskoj ljubavi spram hrvatstva“, u: Isti, Deset krvavih godina i drugi politički eseji, Zagreb 1957., 124-127.

Hrvoje Matković, „Hrvatska zajednica. Prilog proučavanju političkih stranaka u staroj Jugoslaviji“, Istorija XX. veka: zbornik radova, sv. 5, Beograd 1963., 5-136.

Antun Gustav Matoš, Izabrana djela, sv. IV. i VI., Zagreb 1977.

Od Zbora do Velesajma 1909. - 1999. 90 godina Zagrebačkog velesajma (gl. ur. Kruno Sabolić), Zagreb 1999.

Vlatko Pavletić, „Neka bude živost“, Krugovi, 1/1952., 1-7.

Ivo Perić, Zagreb od 1850. do suvremenog velegrada, Zagreb 2006.

Povijest grada Zagreba, knj. 2: 20. i 21. stoljeće, Zagreb 2013.

Dragovan ŠEPIĆ, Jugoslavenski pokret i Milan Marjanović 1901-1919. In memoriam Milanu Marjanoviću, Zagreb 1961.

Zdenka Šımončıć-Boвetкo, Industrija Hrvatske 1918. do 1941. godine (prir. Mira Kolar-Dimitrijević), Zagreb 2005.

Tomislav Timet, Stambena izgradnja Zagreba do 1954. godine, Zagreb 1961.

Zagrebackka panorama, 1/1961., br. 6, 142-145.

Zagrebački električni tramvaj: 105 godina (ur. Vlado Šobota), Zagreb 1996.

Zagrebački leksikon 2 / $M-\check{Z}$, Zagreb 2006.

\section{Mrežne stranice}

Klub željezničkih modelara „Zagreb“

(http://www.kzmz.hr/zanimljivosti.asp?page_id=zanimljivosti)

„Modernitet“, Hrvatski jezični portal (http://hjp.znanje.hr/index.php?show=search)

Milan Ristović, „Jedno viđenje prelomne godine jugoslovenske posleratne kulturne politike (1952)“, 337-352. (https://dokumen.tips/documents/7248-milan-ristovic-jugoslovenske-posleratne-kulturne-politike.html) 